\title{
The role of parents on their children's academic performance
}

\author{
Lan Nguyen $^{a^{*}}$, Nga Duong ${ }^{\mathrm{b}}$, Huyen Dinh ${ }^{\mathrm{c}}$, Mai Nguyen ${ }^{\mathrm{d}}$, and Thoa Nguyen ${ }^{\mathrm{e}}$
}

anternational Cooperation and Scientific Research Department, Van Lang University, Ho Chi Minh city, Vietnam

${ }^{b}$ School of Accounting and Auditing, Foreign Trade University, Hanoi, Vietnam

${ }^{c}$ Faculty of Economics and Technology, Hoa Lu University, Ninh Binh, Vietnam

${ }^{d}$ School of Banking and Finance, Foreign Trade University, Hanoi 100000, Vietnam

${ }^{e}$ School of Accounting, Academy of Finance, Hanoi, Vietnam

\section{H R O N I C L E}

Article history:

Received: July 10, 2020

Received in revised format:

October 122020

Accepted: October 24, 2020

Available online:

October 24, 2020

Keywords:

Academic performance

Academic attainment

Scholastic achievement

GPA

\section{A B S T R A C T}

This study aims to investigate the impact of the family factors on scholastic achievements of students in high schools and universities in Vietnam. The primary data is collected from the 538 students through an online questionnaire. We apply one empirical model with the support of SPSS and STATA to test the family determinants of academic attainments-GPA. We find that there are three factors which impact on GPA of these: Age gap, Income of the families, Negative reactions of parents to their child's low-performed results in academic performance. The research results show that all three factors can explain for $8 \%$ with the changes in GPA of learners. While the age gap between parents and their children has minor positive effects on academic performances, family income is significantly and positively correlated to GPA. This is the reason why students from opulent families often perform better than those of more meager families.

(C) 2021 by the authors; licensee Growing Science, Canada

\section{Introduction}

Academic performance always gathers public and scholarly attention because a generation of well-educated youngsters could drive the economic system to become better. By contrast, academic failure is concerned as one of the reasons behind a chunk of repercussions including substance abuse (Engel et al., 1987) and delinquency (Laub \& Sampson, 1993). Well-performed students tend to have more motivation to work harder, making them more competitive in the labor market before securing a decent job with handsome salary (Zimmerman, 1990). They are also the main force contributing values added to the human resources, the human capital structure of any economy. In contrast, people who have low levels of academic performance tend to drop out of school, skip classes, etc. These people are susceptible to commit crimes or even using illegal products, acting as a deterrent for the whole society and the national economy. In previous studies, academic attainments have been determined by a myriad of factors such as family, school, society, and motivation factors (Aremu, 2000). However, according to Epstein, of all those factors mentioned, parental involvement is of paramount importance (Epstein, 2001). Children with high academic results are likely to be raised in families with the rich in psychological resources, educational resources, socioeconomic resources, and parental involvement (Bloom, 1985; Moon et al., 1998). Previously many researches were carried out on student academic attainment under the basis of gender difference, teaching style, or class environment. To some extent, although several studies have been conducted into the relationships between family and academic success, most of them have been carried in developed countries with significant differences in macro-economic conditions, cultures, and mindsets from Vietnam, so these studies trigger discrepancies in analyzing models and findings and are unlikely to be a suitable concept for

* Corresponding author.

E-mail address: lan.ntn@vlu.edu.vn (L. Nguyen) 
Vietnamese educational system. Furthermore, aforementioned researches have mostly focused on the impact of family background on the attainment of lower education such as primary and secondary schools while scholastic achievements in higher level are still the criteria of universities, further postgraduate programs or even in some recruitment campaign. Therefore, academic results in high schools and universities underlie opportunities of school entering and job landing. Students are given the same knowledge of one specific curriculum at schools, so the diversity of academic outcomes is attributed to parents' participation. Besides, some studies also do not measure the influential determinants of students' learning results Vietnam grading system (10 out of 10 for thesis) but specific subject grade, IQ, or assessments of teachers. Therefore, this paper will concentrate on tackle the controversies by providing a clear definition of academic performance and selecting the most appropriate family factors to measure their impact on academic attainment. By observing 538 youngsters (high schoolers and students of universities) based on the information gathered from an online questionnaire implemented between June 10th to June 23th in Hanoi to fact check our hypotheses, this paper can evaluate and compare the family impact of three different independent variables including Age gap, Income of the families, Negative reactions of parents to their child's low-performed results in academics and the levels of academic achievement. The research results conclude that three family elements are $8 \%$ correlated with GPA of students beyond secondary school.

\section{Literature review}

Academic performance is defined in many ways, depending on personal perspectives of the authors. Some argue that scholastic attainment is simply measured by CPGA (Cumulate Grade Point Average) (Waples \& Darayseh, 2005). Other authors, on the other hand, calculate academic outcomes by using a particular test result or year result (Hake, 1998). No matter how people quantify it, the role in ensuring the "normal functioning" of students' performance is obvious. In this research, we use GPA as an indicator of academic attainment because they are the emblem of student performance for a specific semester (Darling et al., 2005). Of all contributing factors, family elements are more influential in enhancing academic results than schools and communities and there are numerous predictors of it including Age gap, Income of the families, Negative reactions of parents to their child's low-performed results in academic, educational levels of parents and family structure (Epstein, 2001; Coleman, 1996). Previous research has given evidence that parental divorce tends to compromise children's opportunities to succeed in education such a lower GPA (Sun \& Li, 2001) and lower chances of attending universities (Astone \& McLanahan, 1991). Children from divorced families have few chances for educational success due to the decreasing trends in parental finance, time of parental involvement, and approach to community connections (McLanahan \& Sandefur, 1994). There are more residential moves, acting as an incentive for social disconnection and loss of networking, in divorced families compared to non-divorced families. As a result, children experiencing multiple post-divorce family transitions are less likely to have a strong attachment to schools and less likely to give their whole minds to their studies. With research depicting those children of single-parent and stepparent families, rather than normal families, do not have a close-knit relationship with their parents (Furstenberg et al., 1983; Allison \& Furstenberg, 1989). Consequently, the marital status of parents is more and more influential to children especially in terms of spreading their aspirations to their children who are observed with less positive parental interaction. Educational levels of parents are essential predictors of children's scholastic performance because welleducated parents could build a home environment and belief encouraging their children to be successful in academics and facilitating this process (physically, cognitively and emotionally) (Davis-Kean, 2005). These parents could regulate their encouragement and expectation for their children in terms of learning. This is a reason explaining why so many poor people perform distinctly at school without adequate resources (Davis-Kean, 2005; Alexander et al., 1994; Duncan et al., 1994; Okagaki \& Frensch, 1998). Moreover, children's intelligence is not connected with family income but is directly related to educational levels of parents through relative genes influencing cognitive development. High education enables parents to have more opportunities to secure resounding occupations with higher income; however, children in opulent families tend to be more potential enhancement in studying than those of meagre families considered that their parents are brighter rather than have more amount of money (Lemos et al., 2011). Well-educated parents are likely to become role models for their children through achievement behaviors and their attainment orientations for children. By acquiring the valuation of achievements from parents, children could not resist the urge to succeed (Eccles, 1993). Students having well-cultured parents are likely to get more opportunities to perform better than those from low-educated family, given that parents with high scholastic achievements could help their children with school working and give them sounding advice and guidance during schooltime while parents beyond primary schools and secondary school are not able to (Krashen, 2003).

Parent-child age differences could be correlated with the quality of relationships throughout their lives. On one hand, relationships will be enhanced once children get more mature; however, a huge age gap could lighten the likelihood of generations sharing common interests and of them spending time together in general and talking about children's studies in particular (Kaufman \& Uhlenberg, 1998). On the other hand, according to Mac Dougall et al. (2012), older parents are likely to be more emotionally prepared for parenthood; thereby, being able to give more supports to their children especially in both education and experience (Mac Dougall et al., 2012). In 2009, a research found out that besides maternal age, older paternal age was also directly related to impairments in neurocognitive outcomes by giving 56000 US children a multitude of tests including reasoning, memory, learning, understanding, and motors skills. Children with older fathers tended to have lower cognitive test scores, conversely, those with older mothers were likely to perform better on tests of cognitive ability (Barnett et al., 2009). In this research, we expect that age gap will act as a deterrent for academic performance of students. 
Many studies show that family income has a significant impact on child cognitive ability and development (Duncan, 2000; Yeung \& Linver, 2002; Conger et al., 2010). The most famous two models which can be deployed to demonstrate the correlation between family income and children's developmental outcomes are: "the family stress model" and "the family investment model". In line with the family stress model, many authors show the negative influences of poverty on children's development, such as depression, anxiety, and dissatisfaction (Yeung et al., 2002; Mayer, 2002). Such psychological disorders adversely affect youth academic and socio-emotional competence (Brody et al., 1994). Furthermore, parents suffering from financial hardship are more likely to care about making ends meet rather than raising their children. This results in less nurturing and less deeply involved parenting behaviors, which lower educational attainment levels (Flouri, 2004). In other aspects, numerous researches examine how income affects children's achievement through the investment model (Cooper and Steward, 2013; Duncan et al., 1994). They all agree that children from high-income families could attain more education than less well-off children due to parental ability to self-finance the total accumulation of their children's human capital by investing in a quality home environment, health care, learning environment. Hence, family income does play an essential role in the development of children. However, it is not the sole determinant influencing children's academic attainment. Lin and Lv (2017) reveal that there is no great influence of family income on children's academic outcomes in urban families. By contrast, in rural families, an increase in revenue strongly affects children's educational levels. Although the relative importance of economic advantages in determining children's learning outcomes is undeniable, non-monetary factors coming from parents' educational strategies strongly affect children's development. The findings of Datcher-Loury (1989) demonstrate that parental behaviors and attitudes exert a significant influence on children's scholastic achievement even though parents face extremes of financial constraints. Baumrind (1971) also attempts to identify the effects of different parenting styles (e.g., authoritative, authoritarian, and permissive patterns) on children's academic performance. These three family patterns reflect parental discipline and control strategies in terms of values, behaviors, standards, and expectations that parents wish their children to adopt. According to her, authoritarian parents are characterized by high autocracy and low responsiveness, whereas permissive parenting is described by tolerance, little punishment, and few demands. Both authoritarian and permissive parenting styles are proved to produce children with low academic competence (Halle et al., 1997; Dornbusch et al., 1987). In contrast, authoritative parenting provides children with clear guidance and effective communication concerning children's feelings, which in turn promotes social and scholastic competence (Chen et al., 1997; Baumrind, 1971). In this form of parenting practice, children's autonomy and self-determination are encouraged to generate self-esteem, self-regulation under parental instructions, and reasonable control. Children, therefore, can gain intrinsic motivation and adjustment towards the academic domain. Dornbusch et al. (1987) state in their research, authoritative is seen as the most successful parenting to have children with the highest school grades. Furthermore, Steinberg et al., (1989) elaborate on Dornbusch's study, ruling out that students having their parents in a more positive light can attain academic success. In Vietnam, the number of researches investigating the determinants of children's academic performance is minimal. Cuc and Patrick (2010) used a hierarchical linear model (HLM) to analyze a data file of 59,601 students from 64 provinces and 3,975 schools to explore numerous factors affecting student's achievement. Research results assert that student, school, and province characteristics have significant impacts on reading and mathematics scores among Year 5 students in Vietnamese schools. According to Tran (2013), a dysfunctional educational system, inadequate academic motivation, low engagement of parents in children's schooling, and the negative attitudes of teachers and majority students contribute considerably to lower academic attainments of ethnic minority children at secondary levels in Lam Dong Province, Vietnam.

In summary, the results of the literature review above have shown that most national and international researchers focus dominantly on children at specific educational levels and some specific factors affecting student's academic performance. Some studies also evaluate the influential determinants of children's learning outcomes, which is not measured by GPA but specific subject grades in math or reading. Consequently, factors correlated with children's scholastic attainments are not fully identified and analyzed. Furthermore, most practical and theoretical studies are conducted in developed countries with a tremendous gap compared to the Vietnamese social and economic conditions and the education system, leading to differences in analyzing models and findings. In this study, we concentrate on family roles in academic achievement through GPA with the upscale samples of high school and undergraduate students in Hanoi, Vietnam to suggest measures to promote student's academic.

\section{Hypothesis development and research methodology}

\subsection{Hypothesis development}

With a limitation of time and space, the authors only research factors that affect GPA reflecting the grade point average to measure school performance. Those factors include family structures, parental educational levels, age gap between children and parents, family income, time of parental involvement and parental reactions on children's academic performance, the authors focus on building six hypotheses as follows:

\section{$\mathrm{H}_{1}$ : There is a relationship between family structure (STRUC) and children's academic performance.}

Using two waves of the nationally representative data set (NSFH), (Kim, 2004) explores the significant impacts of different types of family structures on children's academic performance. Intact families associated with a stable home environment, 
adequate parental investment in terms of time and money promoting youth's schooling outcomes (Coleman, 1996; Reardon, 2011; Kim, 2004).

\section{$\mathrm{H}_{2}$ : Parental educational levels (EDU_PARE) are positively correlated with children's academic performance.}

Educational levels of parents reflect their cognitive abilities, including knowledge, values, and expectations by which they shape children's behaviors, skills, and attitudes. Well-educated parents are likely to set higher educational goals for their children than other parents (Davis-Kean, 2005); thereby, they create enriching learning environments at home, give clear instructions or proper advice to their children to foster children's academic interests and success (Coley \& Chase-Lansdale, 1998; Luster et al., 2000).

$\mathrm{H}_{3}$ : Age gap between children and parents (AGEGAP) has considerable influences on children's academic performance.

The widening age gap between parents and their children causes differences in views, values, and lifestyles. Due to this, parents find it difficult to show sympathy or encouragement to their offspring or offer them emotional support, which is essential for children's cognitive development. Besides, the generation gap can raise conflicts in a parent-child relationship. Luster and McAdoo (1996) argue that children with negative developmental trajectory cannot achieve high educational levels.

\section{$\mathrm{H}_{4}$ : There is a strong association between family income (INCOME) and children's academic performance.}

According to Conger et al. (2010) and Mayer (2002), the level of family income is positively correlated with children's developmental outcomes. In their research, McLoyd (1998) and Yeung (2002) provide strong evidence for the positive influences between family income and children's academic achievement. This is due to the fact that affluent families can invest more in a quality home environment, health care, learning environment that promotes children's scholastic outcomes.

\section{$\mathrm{H}_{5}$ : Time of parental involvement (TIME) has a positive impact on children's academic outcomes.}

Fan and Chen (2001) conducted a meta-analysis to assert the positive correlation between parental involvement and student's academic outcomes. Similarly, Gonzalez et al. (2002) show that all types of parent involvement were positively related to a mastery orientation in a sample of 196 students in two Florida high schools (Gonzalez et al., 2002). The studies specific to high school context of Ames and Archer (1988) and Duda and Nicholls (1992) also reveal the benefits of parental involvement in the use of mastery goals which is most strongly associated with student's academic performance like the employment of better learning strategies, more positive attitudes, persisting through academic challenges, and experiencing satisfaction in their schoolwork.

$\mathrm{H}_{6}$ : Parental reactions (REACT) are strongly associated with children's academic performance.

Using a large and diverse sample of 7,836 high school students in San Francisco Bay Area, Dornbusch et al. (1987) carried out the research based on Baumrind's parenting typologies to exploit the influences of different parenting styles on children's school performance. They conclude that parents with supportive attitudes are strongly associated with the highest grades of children, while authoritarian and permissive parenting styles are negatively linked with grades (Grolnick \& Ryan, 1989; Grusec \& Goodnow, 1994; Dornbusch et al., 1987). Similarly, Gonzalez et al (2005) agree with this hypothesis and believed that the use of extrinsic rewards in reaction to grades is linked to extrinsic motivation, encouraging and praise is linked to intrinsic motivation, which fosters student's academic achievement. A conceptual framework is displayed in Fig.1

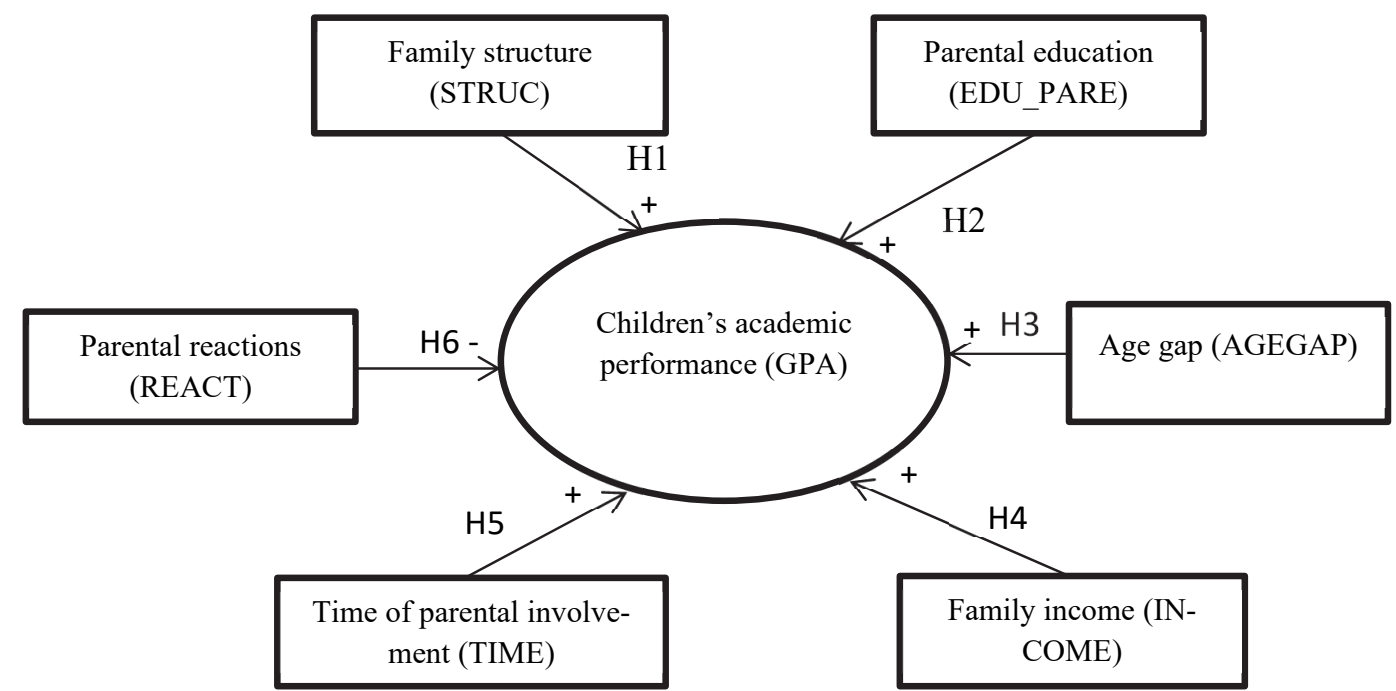

Fig. 1. The family determinants of academic performance 


\subsection{Empirical Model}

In this study, we apply the method of quantitative research into a regression model in which family structure (STRUC), parental education (EDU_PARE), age gap between parents and their offspring (AGEGAP), family income(INCOME), time of parental involvement (TIME) and parental reactions (REACT) are considered as independent variables, whereas GPA used to measured children's academic achievement is the dependent variable. We run the model with the support of STATA 15.1 software to exploit the impact of the aforementioned independent variables on academic outcomes of children from different educational levels in Hanoi, Vietnam.

The model: GPA $=\alpha_{0}+\alpha_{1} \times$ STRUC $+\alpha_{2} \times$ EDU_PARE $+\alpha_{3} \times$ AGEGAP $+\alpha_{4} \times$ INCOME $+\alpha_{5} \times$ TIME $+\alpha_{6} \times$ REACT $+\varepsilon$

where $\alpha_{0}, \alpha_{1}, \alpha_{2}, \alpha_{3}, \alpha_{4}, \alpha_{5}, \alpha_{6}$ are correlation coefficients; $\varepsilon$ is error.

GPA: is the dependent variable, reflecting the grade point average to measure school performance. The point is converted to an 8.5 point scale, whereby $1=$ under $6.5,2=6.5-7.0,3=7.0-8.0,4=8.0-8.5,5=$ over 8.5

STRUC: is the independent variable, identifying the type of family structure. It is characterized by marital status and biological relation to the child. We categorized STRUC into three independent variables: Family with biological parents (STRUC1), single-parent family (STRUC2), and stepfamily (STRUC3). Each is a dichotomous variable $(1=$ Yes, $0=$ No)

EDU_PARE: is the independent variable, identifying the levels of parental education. This is a categorical variable $(1=$ not a high school graduate, $2=$ a high school graduate, $3=$ graduate, $4=$ postgraduate).

AGE GAP: is the independent variable, reflecting the age difference between parents and their children. This is categorical variable $(1=18-20,2=20-30,3=30-40,4=$ over 40$)$.

INCOME: is the independent variable, measuring the family income per month. This is categorical variable $(1=$ under 9 million, 2=9-18 million, $3=18-30$ million, $4=30-45$ million, $5=$ over 45 million).

TIME: is the independent variable, reflecting the frequency of school-related/ learning activities parents are willing to involve in. The frequency is measured based on a Likert scale with a graded score of 1-5 corresponding to the levels of involvement from never, rarely, sometimes, usually, and very usually.

REACT: is the independent variable, reflecting the way parents react to the bad situations in children's learning process such as Bad grades, Complaints from teachers, Lower rank in the class, and Conflict opinion about study. The 1-5 scale ranges from the most positive reactions (Encourage doing better in the future) to the most negative ones (Criticize and Punish).

\subsection{Data collection}

\section{Sample collection and processing process}

Step 1: Define the Research Objects and Scopes: Data were collected from 538 students from different high schools and universities in Hanoi. The group included 343 girls and 195 boys from 16 to 25 years old.

Step 2: Collecting Research Data: We conduct the questionnaires to collect the research information such as personal \& parental information, parental involvement degree questions, etc. Next, we sent directly to the students for their completion under our instructions. Then, we collected all the answers for summarizing and analyzing the data.

Step 3: Processing the Data: the collected data have been compiled in the Microsoft Excel file. Next, we evaluated student's responses by different scales which are defined logically based on the attributes of variables. At the same time, we removed all the invalid \& inconsistent answers. After this step, we have 538 remaining observations.

\section{Sample descriptions}

First, in terms of gender of the students responding, out of 538 surveyed questions, there were 195 students who were male, occupying for 36.2 percent, female survey respondents were 342 students accounting for 63.8 percent. In general, the gender distribution of the surveyed schoolgirls is much larger than the number of schoolboys (more than 148 people, equivalent to 27.6 percent). This is also a percentage consistent with the world trend of society that the research team believes will make the most objective conclusions for this paper.

Regarding education level, it is obvious to see that the number of undergraduates holds the lion's share, accounting for 66.5 percent (over a half) - 358 pupils, followed by high school students at 25.5 percent. The bottom position belongs to postgraduate people at 8.0 percent with $43 / 538$ votes. 


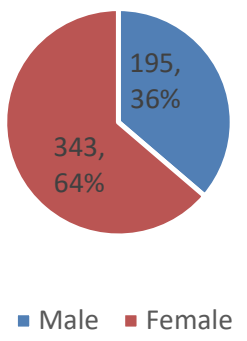

Fig. 2. Gender distribution of participants

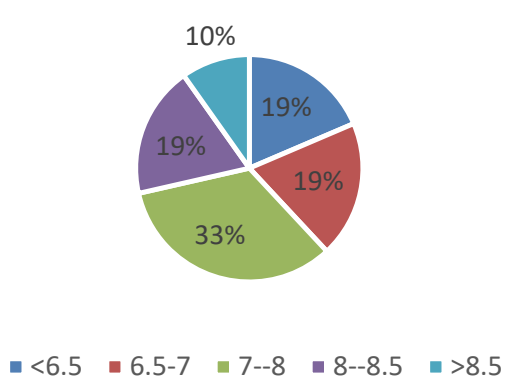

Fig. 3. Academic performance of the participants

Table 1

Educational level of students responding

\begin{tabular}{cccccc}
\hline & & Frequency & Percent & Valid Percent & Cumulative Percent \\
\hline \multirow{6}{*}{ Valid } & 1 & 137 & 25.5 & 25.5 & 25.5 \\
& 2 & 358 & 66.5 & 66.5 & 92.0 \\
& 3 & 43 & 8.0 & 8.0 & 100.0 \\
\cline { 2 - 7 } & Total & 538 & 100.0 & 100.0 & \\
\hline
\end{tabular}

\section{Results}

\subsection{Descriptive statistical results}

Regarding GPA given in Fig. 3, based on common grading in education of Vietnam, the research team divided the GPA ranges into 5 groups including "under 6.5", "from 6.5 to 7.0", "from 7.0 to 8.0", "from 8.0 to 8.5 " and "over 8.5". Based on the results collected and synthesized from the research team, pupils from group "from 7.0 to 8.0" account for a completely superior rate compared to other pupil segments with 180 people (33.5 percent). The proportions of respondents from GPA-group "under 6.5", "from 6.5 to 7.0" and "from 8.0 to 8.5" are similar, at 18.6 percent (100people), 19.5 percent (105 people) and 18.8 percent (101 people). However, from the GPA of 8.5 and up, the number of participants accounted for only 9.7 percent, equivalent to 52 students. All correlations among variables in the model are less than 0.4 ; therefore, multicollinearity will not happen.

Table 2

Correlation among variables in the model

\begin{tabular}{cccccc}
\hline & EDU PARE & AGEGAP & INCOME & TIME \\
\hline EDU_PARE & 1 & & & & \\
AGEGAP & 0.1198 & 1 & 1 & \\
INCOME & 0.279 & 0.0343 & 1 & \\
TIME & 0.1056 & 0.0082 & 0.0575 & \\
REACT & 0.0068 & 0.0362 & -0.0137 & -0.2467 \\
\hline
\end{tabular}

\subsection{Regression analysis}

In Table 3, F_test $=4.53\left(\mathrm{P}_{-}\right.$value $\left.=0\right)$, which is less than 0.05 , presents that beta of the independent variables in the model never jointly equal 0 or all these variables are statistically significant. With the confidence level of $95 \%$, it can be said that the model is sensible.

Table 3

The summary of ANOVA test

\begin{tabular}{cccc}
\hline Source & SS & df & MS \\
\hline Model & 62.8983989 & 10 & 6.28983989 \\
Residual & 732.514241 & 527 & 1.3899701 \\
\hline Total & 795.412639 & 537 & 1.48121534
\end{tabular}

$\mathrm{F}(10,527)=4.53$ Prob $>\mathrm{F}=0.0000$ R-squared $=0.0791$ Adj R-squared $=0.0616$ Root $\mathrm{MSE}=1.179$

The adjusted R squared value is 7.91 percent, meaning that the changes in GPA are approximately 8 percent related to the changes in the independent variables in the model. This phenomenon is understandable given that there are a myriad of other factors exercising influences on GPA, namely, factors from self-learning-awareness, teachers, and academic curriculum. In Table 4, since the p-values ( $\mathrm{t}$-test) of the three independent variables AGEGAP, INCOME, and REACT in the model are all less than 0.05 , they are statistically significant. Unlike EDU_PARE, TIME and FAMISTRUCTURE have a p-value (t-test) 
of 0.182, greater than 0.05. As a result, EDU_PARE, TIME, and FAMISTRUCTURE, which are not statistically significant in the model, should be eliminated from the model.

Table 4

The results of regression analysis

\begin{tabular}{ccccccc}
\hline GPA & Coef. & Std. Err. & $\mathrm{t}$ & $\mathrm{P}>|\mathrm{t}|$ & \multicolumn{2}{c}{$95 \%$ Conf. Interval } \\
\hline EDU PARE & 0.0894464 & 0.0669162 & 1.34 & 0.182 & -0.0420089 & 0.2209016 \\
AGEGAP & 0.0179118 & 0.0090771 & 1.97 & 0.049 & 0.0000801 & 0.0357434 \\
INCOME & 0.2234525 & 0.0525697 & 4.25 & 0.000 & 0.1201805 & 0.3267244 \\
TIME & -0.0414386 & 0.0724533 & -0.57 & 0.568 & -0.1837714 & 0.1008941 \\
REACT & -0.1538383 & 0.0626283 & -2.46 & 0.014 & -0.2768701 & -0.0308065 \\
Family with both care & 0.3116682 & 0.2866443 & 1.09 & 0.277 & -0.2514376 & 0.874774 \\
Single parent & 0.1396133 & 0.3536985 & 0.39 & 0.693 & -0.5552188 & 0.8344451 \\
Step family & -0.6134788 & 0.5656113 & -1.08 & 0.279 & -1.724609 & 0.4976509 \\
EDU & -0.0504657 & 0.0960307 & -0.53 & 0.599 & -0.2391157 & 0.1381842 \\
GENDER & -0.0069263 & 0.1073539 & -0.06 & 0.949 & -0.2178203 & 0.2039678 \\
cons & 2.045942 & 0.5434867 & 3.76 & 0.000 & 0.9782759 & 3.113609 \\
\hline
\end{tabular}

More specifically, the positively correlations between AGEGAP and the dependent variable are always really weak at $1.79 \%$.

However, INCOME is positively related to GPA, at 22.35 percent, which is a strong relationship, which is consistent with the literature (Becker \& Tomes, 1986)because, with high income, they are willing to invest in quality home environment, health care, learning environment to promote their children's mental and physical development. Cognitive abilities, schooling achievement, and engagement are improved accordingly. This result is opposite the opinion of Lemos et al. (2011) that students from families with higher income tend to have better academic attainments than those from others because of the brightness of parents in the former families instead of their money. Analysis of the independent value REACT (negative reaction) shows that it is negatively related to GPA in the given period. If the level of negative reaction of parents increases to the next level, GPA of their children will decrease 15.38 percent. Two demographic factors do not have any impact on GPA. In other words, t-test of EDU and GENDER are not statistically significant in the model.

\section{Conclusions}

The research team has self-developed a research model with 5 independent variables, 1 dependent variable, and test and measure their impact on GPA of students who responded. From the opinions and data of the survey, the team found a consensus: There are three family determinants that influence on academic performance of high school and university students in Vietnam: Age gap, Income of the families, Negative reactions of parents to their child's low-performed results in academics. Conversely, EDU_PARE, TIME, and FAMISTRUCTURE are not statistically significant in the model.

Specifically, the factor that has the most significant influence in shaping academic performance is income of family. Negative reactions of parents to their child's low-performed results in academics, on the other hand, is negatively related to GPA of students. From the research results presented in section 4, we propose the following recommendations:

- The educational levels of students are assumed to be elevated by the increase in home income. Poor children are likely to be exposed to school deficits and physical and mental illnesses, which hinder their development. To reduce the negative impact of income on the student's schooling outcomes, the State should provide financial aids to support students with economic difficulties; uphold the educational fairness and quality to ensure the equitable distribution of educational resources.

- As a place of conveying knowledge and educating people, high schools and universities should invest in upgrading facilities to create a good learning environment. Besides, they must establish and maintain close ties with students and their families to understand their circumstances and have reasonable measures to improve school quality. Furthermore, they should provide disadvantaged students with scholarships, hardship funds, or loans to reduce the rate of dropping out of school. Free or discounted course books should also be given to students to encourage them to engage in learning activities to achieve higher academic attainment.

- Parents, as the person closest to their children, they should create comfortable and positive home environments for their children to cultivate their learning interests. Moreover, they should concentrate on education investment and more proactive actions in learning process with their children. Instead of exerting any power over their children or applying heavy punishment, they should do play the role of a friend, a teacher, positive parents who understand children's learning difficulties, feelings or wishes, and set academic goals suitable for their children's abilities. Children, therefore, feel free from stress and find motivation in learning to get schooling success.

- Students should keep motivation, self-regulation, and positive behavior towards learning. Additionally, they should build a set of goals to track their progress and plan their time effectively to achieve specific academic targets. 


\section{References}

Aremu, A. O. (2000). Impact of home, school and government on primary school pupils' academic performance. The Exceptional Child, 5(1), 106-110.

Alexander, K. L., Entwisle, D. R., \& Bedinger, S. D. (1994). When Expectations Work: Race and Socioeconomic Differences in School Performance. Social Psychology Quarterly, 57, 283-299.

Allison, P. D., \& Furstenberg, F. F. (1989, Juy). How marital dissolution affects children: Variations by age and sex. Developmental Psychology, 25(4), 540-549.

Ames, C., \& Archer, J. (1988). Achievement goals in the classroom: Students' learning strategies and motivation processes. Journal of Educational Psychology, 80(3), 260.

Astone, N. M., \& McLanahan, S. S. (1991). Family structure, parental practices and high school completion. American Sociological Review, 56, 309-320.

Barnett, A. G., Saha, S., Foldi, C., Burne, T. H., Eyles, D. W., Buka, S. L., et al. (2009). Advanced paternal age is associated with. PlosMed, 6(3), 1-9.

Baumrind, D. (1971). Current patterns of parental authority. Developmental Psychology, 4(1), 1-103. doi:10.1037/h0030372.

Becker, G. S., \& Tomes, N. (1986, July). Human capital and the rise and fall of families. Journal of Labor Economics, 4, S1S39.

Bloom, B. L. (1985, June). A factor analysis of self-report measures of family functioning. Family Process, $24(2), 225-239$.

Brody, G. H., Stoneman, Z., Flor, D., McCrary, C., Hastings, L., \& Conyers, O. (1994). Financial resources, parent psychological functioning, parent co-caregiving, and early adolescent competence in rural two-parent African-American families. Child development, 65(2), 590-605.

Chen, X. D. (1997). Authoritative and Authoritarian Parenting Practices and Social and School Performance in Chinese Children. International Journal of Behavioral Development, 21(4), 855-873.

Coleman, J. C. (1996). Washington, DC: U.S. Department of Health, Education, and Welfare. Equality of educational opportunity.

Coley, R. L.-L. (1998). Adolescent pregnancy and parenthood: Recent evidence and future directions. American Psychologist, $53,152-166$.

Cooper, K., \& Steward, K. (2013). Does money affect children's outcomes?

Conger, R. D., \& Conger, K. J. (2010). Socioeconomic status, family processes, and individual development. Journal of Marriage and Family, 72(3), 685-704.

Darling, N., Caldwell, L. L., \& Smith, R. (2005). Participation in school-based Extracurricular Activities and Adolescent Adjustment. Journal of Leisure Research, 37, 51-76.

Datcher-Loury, L. (1989). Family background and school achievement among low income blacks. The Journal of Human Resources, 24, $528-543$.

Davis-Kean, P. (2005). The influence of parent education and family income on child achievement: The indirect role of parent expectations and the home environment. Journal of Family Psychology, 19, 294 -304.

Dornbusch, S. M., Ritter, P. L., Leiderman, P. H., Roberts, D. F., \& Fraleigh, M. J. (1987). The relation of parenting style to adolescent school performance. Child Development, 58(5), 1244-1257.

Duda, J. L. (1992). Dimensions of achievement motivation in schoolwork and sport. Journal of Educational Psychology, 84(3), 290-299.

Duncan, G. J. (2000). Family poverty, welfare reform, and child development. Child Development, 71(1), $188-196$.

Duncan, G. J., \& Brooks-Gunn, J. (2000). Family poverty, welfare reform, and child development. Child Development, 71(1), $188-196$.

Duncan, G. J., Brooks-Gunn, J., \& Klebanov, P. K. (1994). Economic deprivation and early childhood development. Child Development, 65(2), 296-318.

Epstein, J. L., Sanders, M. G., Sheldon, S. B., Simon, B. S., Salinas, K. C., Jansorn, N. R., ... \& Hutchins, D. J. (2001). School, family, and community partnerships: Your handbook for action. Corwin Press.

Eccles, J. S. (1993). School and family effects on the ontogeny of children's interests, self-perceptions, and activity choices. Nebraska Symposium on Motivation: Vol. 40. Developmental perspectives on motivation, 145-208.

Engel, U., Nordlohne, E., Hurrelmann, K., \& Holler, B. (1987). Educational career and substance use in adolescence. European Journal of Psychology of Education, 2(4), 365.

Fan, X., \& Chen, M. (2001). Parental involvement and students' academic achievement: A meta-analysis. Educational Psychology Review, 13, 1-22.

Flouri, E. \&. (2004). Early father's and mother's involvement and child's later educational outcomes. British Journal of Educational Psychology, 74(2), 141-153.

Furstenberg, F. F., Nord, C. W., Peterson, J. L., \& Zill, N. (1983). The life course of children of divorce: Marital disruption and parental contact. American Sociological Review, 48, 656-668.

Gonzalez, A. D. (2002). High school students' goal orientations and their relationship to perceived parenting styles. Contemporary Educational Psychology, 27, 450-470.

Gonzalez-DeHass, A. R. (2005). Examining the Relationship Between Parental Involvement and Student Motivation. Educational Psychology Review, 17(2), 99-123. doi:10.1007/s10648-005-3949-7. 
Grolnick, W. S., \& Ryan, R. M. (1989). Parent styles associated with children's self-regulation and competence in school. Journal of Educational Psychology, 81(2), 143.

Grusec, J. E. (1994). Impact of parental discipline methods on the child's internalization of values: A reconceptualization of current points of view. Developmental Psychology, 30(1), ,4-19.

Hake, R. R. (1998). Interactive-engagement versus traditional methods: A six-thousand-student survey of mechanics test data for introductory physics courses. American Journal of Physics, 66(1), 64-74.

Halle, T. G.-C. (1997). Family influences on school achievement in low-income, African American children. Journal of Educational Psychology, 89(3), 527-537. https://doi.org/10.1037/0022-0663.89.3.527.

Kaufman, G., \& Uhlenberg, P. (1998, November). Effects of life course transitions on the quality of relationships between adult children. Journal of Marriage and Family, 60, 924-938.

Kim, H. J. (2004). Family resources and children's academic performance. Children and Youth Services Review, 26(6), 529536.

Krashen, S. D. (2003). Explorations in Language.

Laub, J. H., \& Sampson, J. R. (1993). Crime in the making: Pathways and turning points through life. Criminology, 31(3), 301-326.

Lemos, G. C., Almeida, L. S., \& Colom, R. (2011). Intelligence of adolescents is related to their parents' educational level. Personality and Individual Differences, 50(7), 1062-1067.

Lin, T., \& Lv, H. (2017). The effects of family income on children's education: An empirical analysis of CHNS data. In Proceeding on the 4th International Conference on Information Technology and Career Education Asian Academic Presspp (pp. 49-54).

Luster, T. B. (2000). Factors related to successful outcomes among preschool children born to low-income adolescent mothers. Journal of Marriage and the Family, 62, 133-146.

Luster, T., \& McAdoo, H. (1996). Family and child influences on educational attainment: a secondary analysis of the high/scope Perry Preschool data. Developmental Psychology, 32(1), 26.

Mac Dougall, K., Beyene, Y., \& Nachtigall, R. D. (2012). 'Inconvenient biology:' advantages and disadvantages of first-time parenting after age 40 using in vitro fertilization. Human Reproduction, 27(4), 1058-1065.

Mayer, S. E. (2002). The influence of parental income on children's outcomes. Wellington, New Zealand: Knowledge Management Group, Ministry of Social Development.

McLanahan, S., \& Sandefur, G. (1994). Growing Up with a Single Parent. What Hurts, What Helps. London: Harvard University Press.

McLoyd, V. C. (1998). Socioeconomic disadvantage and child development. American Psychologist, 53(2), $185-204$. doi:10.1037/0003-066x.

Moon, S. M., Jurich, J. A., \& Feldhusen, J. F. (1998). Families of gifted children: Cradles of development. Talent in context: Historical and social perspectives, 81-99.

Okagaki, L., \& Frensch, P. A. (1998). Parenting and children's school achievement: A multiethnic perspective. American Educational Research Journal, 35(1), 123-144.

Reardon, S. (2011). The widening achievement gap between the rich and the poor: New evidence and possible explanations. In G. J. Duncan \& R. J.Mumane (Eds.). Whither opportunity? Rising inequality, schools and children's life chances, (pp.91-116). New York, NY: Russell Sage Foundation.

Steinberg, L. E. (1989). Authoritative parenting, psychosocial maturity, and academic success among adolescents. Child Development, 60(6), 1424. doi:10.2307/1130932.

Sun, Y., \& Li, Y. (2001). Marital disruption, parental investment and children's academic achievement: a prospective analysis. Journal of Family Issues, 22, 27-62.

Tran, N. (2013). Factors associated with low educational motivation among ethnic minority students in Vietnam. Ritsumeikan Journal of Asia Pacific Studies, 32, 124-136.

Waples, E., \& Darayseh, M. (2005). Determinants of students' performance. Journal of College Teaching \& Learning, 2, 8792.

Yeung, W. J., \& Linver, M. R.-G. (2002). How money matters for young children's development: Parental investment and family processes. Child Development, 73(6), 1861-1879.

Yeung, W. J.-G. (2002). How Money Matters for Young Children's Development: Parental Investment and Family Processes.

Zimmerman, B. J. (1990). Self-regulated learning and academic achievement: The emergence of a social cognitive. Educational Psychology Review, 2, 173-201. 
(C) 2021 by the authors; licensee Growing Science, Canada. This is an open access article distributed under the terms and conditions of the Creative Commons Attribution (CC-BY) license (http://creativecommons.org/licenses/by/4.0/). 